klart og godt. Jeg savner nok et register, men det er ikke så viktig. Konklusjonen er at dette er en god og viktig bok som bør leses av mange. Den bør leses av pasienter og pårørende, og den bør også leses av fastleger og personell i hjemmetjenestene, slik at de kan hjelpe pasientene sine på «Veien tilbake til livet». Jeg tror at dette er den beste boken jeg har lest på dette feltet, og den fortjener å få mange lesere.

Peter F. Hjort

Blommenholm

\section{Epileptologi for alle}

Karl Otto Nakken Epilepsi

238 s, tab, ill. 2. utg. Oslo: Cappelen Damm, 2010. Pris NOK 399

ISBN 978-82-02-32687-6

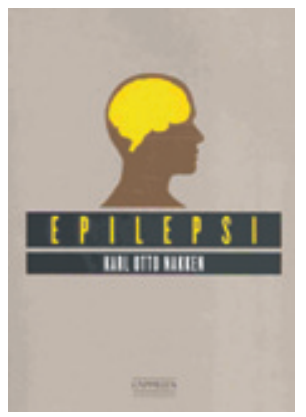

Denne norske læreboken i epilepsi fikk en god mottakelse da den utkom i første utgave i 2003. Når den nå foreligger i ny utgave, er det ikke de store grepene som preger oppdateringen. Kapitlene, inkludert underkapitlene, er eksakt de samme. Fysisk er den akkurat like stor som før, i paperback. Totalt er sidetallet krympet med 13 sider, men det skyldes kun at referanselisten, som i første utgave kom til slutt i hvert kapittel, nå er samlet bakerst. Det oppleves ryddigere, og når teksten nå er ført i to spalter, synes jeg også den er blitt mer oversiktlig. En detaljert innholdsfortegnelse gjør stikkordregister overflødig, men dessverre stemmer ikke sidetallene. Fra side 47 oppstår det en feil som bare øker, slik at de siste sidehenvisningene er hele ti sider ute av kurs.

Hva er så nytt i andre utgave? For det første er boken selvsagt faglig oppdatert. Blant annet er hele fem nye antiepileptika kommet på markedet siden første utgave, og de er alle behørig omtalt, også preparatet som ble lansert i april 2010. For det andre er det gjort et godt arbeid for å forbedre språket. Førsteutgaven inneholdt en del vanskelige faguttrykk som nå stort sett er luket bort, slik at boken er langt lettere tilgjengelig for pasienter, pårørende og ikkemedisinere som arbeider med epilepsipasienter, f.eks. er «komorbiditet» blitt til «tilleggsproblemer», «katamenial» er blitt til «menstruasjonsrelatert», og der det før sto «ekstrapoleres til human epilepsi» står det nå «overføres til epilepsi hos mennesker».
Spesielt godt likte jeg den nesten poetiske endringen av tittelen i kapittel 9, fra «Differensialdiagnoser» til «Anfall i epilepsiens grenseland».

En ting en bok som dette kanskje kunne inneholdt, var en beskrivelse av hvordan epilepsiomsorgen i Norge er organisert. Det er vanskelig både for leg og lærd å sette seg inn i hvilken oppgavefordeling som gjelder mellom første- og annenlinjetjenesten, mellom universitetssykehusene og «Epilepsisenteret-SSE» som det heter for tiden, og ikke minst hvilken rolle de ulike private institusjonene har.

Alt i alt fremstår denne utgaven som en faglig oppdatert og språklig forbedret fremstilling av fagfeltet epilepsi på norsk. Jeg vil tro at den vil oppfattes som lettere tilgjengelig for ufaglærte lesere, uten at det har gått på bekostning av fagligheten. Jeg anbefaler den til alle som på en eller annen måte har med epilepsipasienter å gjøre.

\section{Geir Bråthen}

Avdeling for nevrologi og klinisk nevrofysiologi St. Olavs hospital

\section{Om å søke etter behandling for autisme}

Rupert Isaacson

Hestegutten

En fars kamp for sin autistiske $s ø n n .317$ s, ill. Oslo: Bazar Forlag, 2010. Pris NOK 349 ISBN 978-82-8087-316-3

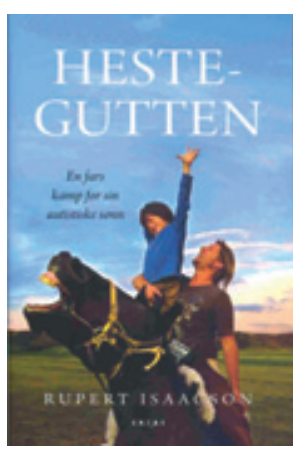

Faren til en gutt som får diagnosen autisme tre år gammel, beskriver hvordan det er, gradvis å forstå at det førstefødte barnet, som han har mange forventninger til, utvikler seg annerledes enn andre barn. Han forteller om jakten på noen som forstår sønnen, og som kan gi gutten en behandling som virker. Dette er en beretning om ikke bare sorgen foreldre opplever når de må erkjenne at deres barn har en alvorlig lidelse, men også om et brutalt møte med velmenende menneskers ubrukelige råd, om behandling som ikke virker, som er krevende å gjennomføre, og som setter foreldrenes samhandling på prøve. Forfatteren dveler likevel ikke med dette, boken handler mest om en ukuelig vilje til å prøve alt. Familien reiser for eksempel til Mongolia og Sibir for å møte sjamaner i håp om å få hjelp.

Dette er vakkert og velskrevet om en smertefull prosess. Og man făr en reise- skildring på kjøpet; faren er reisebokforfatter. Alle foreldre til barn med autisme vil kjenne seg igjen, til tross for at dette er en uvanlig historie. Forløpet av autisme gjennom førskolealderen, slik den beskrives, er ikke uvanlig. Å kunne si noe om hva som egentlig virket når gutten begynner å snakke og blir renslig, er uinteressant i denne historien, fordi det er en historie om tro, håp og kjærlighet til sitt barn, $\mathrm{og}$ om ikke å gi opp. Historien gir innsikt i de enorme kreftene foreldre har når de kjemper for sitt barn. Dette er en far som intuitivt og sensitivt er på guttens banehalvdel, noe mange foreldre ofte er. På den måten er det en bok som behandlere har noe å lære av. Det er også en tankevekkende historie som utfordrer en medisinsk, rasjonell tradisjon.

\section{Eili Sponheim}

Enhet forskning psykisk helse barn og ungdom Oslo universitetssykehus, Ullevål

\section{Lykke kan læres}

Sarah Zobel Kølpin

Lev deg lykkelig - med positiv psykologi

180 s, ill. Oslo: Engelstad Forlag, 2010.

Pris NOK 249

ISBN 978-82-92533-21-5

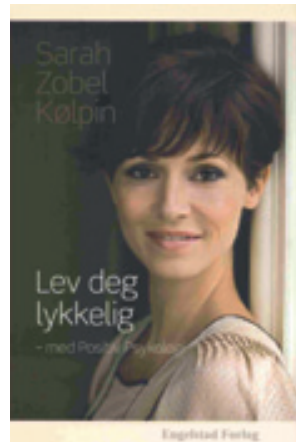

Forfatteren er en dansk psykolog som skriver at lykke kan læres. Med lykke mener hun en vedvarende følelse av tilfredshet og livsglede. En slik tilstand kan oppnås, til tross for livets opp- og nedturer og normale humørsvingninger. Kølpin tar for seg positiv psykologi, som er noe annet enn positiv tenkning. Teorien/metoden bygger på fire søyler: positive følelser, engasjement, mening og positive relasjoner. Det kreves et aktivt arbeid for å bli mer tilfreds, mer takknemlig og mer lykkelig. Hun beskriver at viljen er en viktig faktor for å oppnå lykke, og at det faktisk kommer mer an på hvordan vi tar det, enn hvordan vi har det. $\AA$ være lykkelig beskrives som en tilstand, noe varig, ikke bare fravær av ulykke eller et kort blaff av lykke.

Boken, med sitt perspektiv på salutogenese, inneholder et viktig bidrag til den tradisjonelle, problemfokuserte psykiatrien. Søkelyset er altså rettet mot hva som bringer helse, i motsetning til årsakene til sykdom.

Den er lagt opp som en selvhjelpsbok, men er på en ærlig måte preget av at det 